\title{
Restriction of DNA in Yersinia enterocolitica Detected by Recipient Ability for a Derepressed R Factor from Escherichia coli
}

\author{
By G. CORNELIS \\ Laboratoire de Microbiologie, Université de Louvain, B3000 Leuven, Belgium \\ AND C. COLSON \\ Laboratoire de Cytogénétique, Université de Louvain, BI 348 Louvain-La-Neuve, \\ Belgium
}

(Received 30 September 1974)

\begin{abstract}
SUMMARY
A derepressed R factor, RY2drd2, was transferred at a frequency of $5 \times 10^{-3}$ between two strains of Yersinia enterocolitica mated on a membrane. Under the same conditions transfer of this R factor from Escherichia coli to Y. enterocolitica was observed at a frequency of only $7 \cdot 7 \times \mathrm{IO}^{-6}$. This frequency was greatly increased when the recipient strain was heat-treated before mating. Heat exposure for optimum fertility was 50 to $52{ }^{\circ} \mathrm{C}$ for a period of 2 to 3 min. Mutants of $Y$. enterocolitica were isolated which were infected by RY $2 d r d 2$ from $E$. coli or from $Y$. enterocolitica at the same frequency. These observations strongly suggest that a DNA restriction and modification system in $Y$. enterocolitica causes its low recipient ability for plasmids from other species.
\end{abstract}

\section{INTRODUCTION}

The first report of the transfer of an $\mathrm{F}$ episome to a species in the genus Yersinia was that of Flac ${ }^{+}$to $Y$. pestis (Martin \& Jacob, 1962). Lawton, Morris \& Burrows (I968) observed Flac ${ }^{+}$-mediated transfer of chromosome between auxotrophic strains of $Y$. pseudotuberculosis. Thus chromosomal mapping in this species was initiated (Morris \& Burrows, I968; Lawton \& Stull, I97I), and developed by the use of an Hfr clone (McMahon, I97I, I973).

Chromosomal transfer mediated by an FCM was also reported in $Y$. pestis (Lawton \& Stull, 1972). However, the same authors found no chromosomal transfer mediated by Flac ${ }^{+}$ or FCM plasmid in $Y$. enterocolitica.

The recipient ability of $Y$. pestis and $Y$.pseudotuberculosis for $\mathrm{R}$ factors was demonstrated soon after the discovery of these plasmids (Ginoza \& Matney, I963). Transfer of R factors to $Y$. enterocolitica was obtained by Knapp \& Lebek (1967) and by Rusu, Baron \& Lazaroae (1970). Recently, strains of $Y$. enterocolitica carrying $\mathrm{R}$ factors have been found in nature (Cornelis, Wauters \& Bruynoghe, 1973a; Cornelis, Wauters \& Vanderhaeghe, 1973b). However, $\mathrm{R}$ factor-carrying $Y$. enterocolitica isolates are rare and experimental transfer of F or R factors from Escherichia coli or Shigella flexneri to species of Yersinia occurs at low frequency.

We have considered the possibility that this low frequency resulted from the degradation of foreign DNA by restriction and modification (R-M) systems. These R-M systems consist of two enzymes. One, the restriction endonuclease, causes double strand breaks in invading DNA whereas the other, the modification methylase, protects the DNA of the bacterial cell itself by methylation of a base on both strands of the nucleotide sequence specific for the 
Table I. Bacterial strains

\begin{tabular}{|c|c|c|c|c|}
\hline Species & Strain number & Serotype & Relevant genotype & Origin \\
\hline Escherichia coli $\mathrm{KI} 2$ & $\begin{array}{l}\text { Richter } \\
84 \mathrm{NX}\end{array}$ & & $\begin{array}{l}\text { Defective } \mathrm{Hfr} \\
\mathrm{F}^{-} \text {met cys try lac nal }\end{array}$ & $\begin{array}{l}\text { E. Meynell } \\
\text { P. Frédéricq }\end{array}$ \\
\hline \multirow[t]{5}{*}{ Yersinia enterocolitica } & $\begin{array}{l}\text { W222 } \\
\text { W230 }\end{array}$ & $\begin{array}{l}O: 3 \\
0: 3\end{array}$ & $\begin{array}{l}\text { Wild type } \\
\text { Wild type }\end{array}$ & $\begin{array}{l}\text { From man } \\
\text { From pig }\end{array}$ \\
\hline & $\left.\begin{array}{l}\text { W227 } \\
\text { w277 }\end{array}\right\}$ & $0: 9$ & Wild type & From man \\
\hline & W2270I & $0: 9$ & str & From $w_{227}$ \\
\hline & $\left.\begin{array}{l}w 22702, w 22705 \\
w 22707, w 22709\end{array}\right\}$ & $0: 9$ & - & From $w 227^{*}$ \\
\hline & w22708 & $0: 9$ & str & $\begin{array}{l}\text { From } \\
\text { W22703 }\end{array}$ \\
\hline
\end{tabular}

endonuclease (review: Meselson, Yuan \& Heywood, I972). R-M systems were first discovered and extensively studied in E. coli (review: Arber \& Linn, 1969), but have been detected in many Gram-negative bacilli, including Salmonella typhimurium (Colson \& Colson, 1967), Shigella flexneri (Falkow \& Formal, 1969), Citrobacter freundii (de Graaf \& Stouthamer, 197I) and Pseudomonas aeruginosa (Rolfe \& Holloway, 1969).

We report on the recipient capacity of four strains of $Y$. enterocolitica for plasmid DNA from $E$. coli and present evidence which indicates that these strains exercise DNA restriction.

\section{METHODS}

Bacterial strains. All the strains are listed in Table I. The Y. enterocolitica strains were from the collection'of Professor G. Wauters, Department of Microbiology, University of Louvain. These strains were of serotype 3 or 9 (Winblad, 1967; Wauters, Le Minor \& Chalon, 1971). These serotypes belong to two different biotypes (Nilhen, I969; Wauters, 1970) and are those to which most strains encountered in man belong.

Plasmids. An Flac ${ }_{1}^{+}$episome from strain 94 of R. C. Clowes was received from Professor $P$. Frédéricq. The R factor RY2drd2 is a derepressed mutant of RY2 (fi $+\mathrm{Km} \mathrm{Cm} \mathrm{Sm} \mathrm{Su}$ ) found in the strain) $Y$. enterocolitica 857 (Cornelis et al. I973a). This mutant was obtained by the method of Meynell \& Datta (1967). Wild-type RY2 was introduced into strain Richter which was then treated with $N$-methyl- $N^{\prime}$-nitro- $N$-nitrosoguanidine (NTG; Fluka) (Ioo $\mu \mathrm{g} / \mathrm{ml}$, $\mathrm{pH} 6$ for $25 \mathrm{~min}$ ).'Plates bearing semi-confluent colonies were replicated to lawns of $84 \mathrm{NX}$ (met cys try $l a c^{+}$) on plates of citrate Simmons agar as minimal medium (Frédéricq \& Delhalle, I972) supplemented'with lactose, cysteine and tryptophan. Out of 16 clones of $84 \mathrm{NX}$ growing in the absence of methionine and containing RY2, two were lysed by the male specific phages $\mathrm{f} \mathbf{I}$ and $\mathrm{f} 2$.

Media. The complete media were nutrient broth (Difco), MacConkey agar (Difco) and brain-heart agar (Difco) supplemented with $10 \%$ blood. The minimal medium for $Y$. enterocolitica was that described by Burrows \& Gillett (I966) supplemented with $5 \mu \mathrm{g}$ thiamine $/ \mathrm{ml}$. All incubations of $Y$. enterocolitica were performed at $28{ }^{\circ} \mathrm{C}$.

Mutagenesis. Cultures of $Y$. enterocolitica were mutagenized by a $15 \mathrm{~min}$ treatment with I00 $\mu \mathrm{g} \mathrm{NTG/ml} \mathrm{in} 0.067 \mathrm{M}$-phosphate buffer at $\mathrm{pH}$. The bacteria were washed twice, diluted in broth and incubated overnight.

Heat-treatment of the recipient followed by mating in liquid. A three $\mathrm{ml}$ sample of an $\mathrm{I} 8 \mathrm{~h}$ culture in broth of the recipient strain was centrifuged and the bacteria were resuspended in 
$0.05 \mathrm{ml}$ saline pre-heated to the chosen temperature. At fixed times, the cell suspensions were iransferred to an ice bath, allowed to cool and centrifuged. The pellet of bacteria was immediately resuspended in $0.5 \mathrm{ml}$ of an exponential culture of the donor and the mixtures were kept at $37^{\circ} \mathrm{C}$ for 60 or $90 \mathrm{~min}$.

Mating on membranes. An overnight culture of the donor strain was diluted I: Io in fresh broth and incubated for $2 \frac{1}{2} \mathrm{~h}$ at $37^{\circ} \mathrm{C}$. Three $\mathrm{ml}$ of this culture were mixed with $5 \mathrm{ml}$ of an overnight culture of the recipient strain and the mixture was filtered on a $25 \mathrm{~mm}$ Millipore membrane. The membrane was placed on the surface of a plate of brain-heart agar supplemented with blood and incubated for $2 \mathrm{~h}$ at $37^{\circ} \mathrm{C}$. The membrane was then removed and the bacteria were resuspended in $2 \mathrm{ml}$ saline, diluted and plated. The frequencies of transfer were calculated in respect of donor input.

Selections. The bacteria carrying RY2drd2 were selected on $\mathrm{I} 6 \mu \mathrm{g}$ chloramphenicol $/ \mathrm{ml}$; $Y$. enterocolitica were selected on $35 \mu \mathrm{g}$ carbenicillin/ml (Cornelis et al. $1973 b$ ); E. coli $84 \mathrm{NX}$ was selected on $16 \mu \mathrm{g}$ nalidixic acid/ml; W2270I and W22708 were selected on $1000 \mu \mathrm{g}$ streptomycin/ml.

Curing. Spontaneous $\mathrm{R}^{-}$segregants of $Y$. enterocolitica were obtained by subculturing the corresponding $\mathrm{R}^{+}$strains (Cornelis et al. 1973 a).

\section{RESULTS}

\section{Effect of pre-heating on the recipient ability of $Y$. enterocolitica}

It was observed in preliminary experiments that pre-heating cultures of $Y$. enterocolitica at $50{ }^{\circ} \mathrm{C}$ before mating in liquid with $E$. coli donors allowed the recovery of Flac ${ }^{+}-$or RY2drd2-infected $Y$. enterocolitica clones at a significantly higher frequency than without heat treatment.

Two types of experiments were performed to determine the conditions of heat-treatment for optimal transfer of RY2drd2 from E. coli to Y. enterocolitica w227. In the first set of experiments, a culture of the recipient bacteria was divided into $3 \mathrm{ml}$ samples that were exposed for I min to temperatures from 42 to $60{ }^{\circ} \mathrm{C}$ as described in Methods. Each treated sample was mixed with $0.5 \mathrm{ml}$ of a single culture of the donor. The results of five independent experiments are summarized in Fig. I. Although the absolute optimum frequency of transfer varied widely among experiments (from $\mathrm{I} \times \mathrm{IO}^{-7}$ to $5 \times 10^{-6}$ ) the optimum was always within the range 50 to $52{ }^{\circ} \mathrm{C}$. Transfer was never observed (under these conditions) to recipient cells pre-heated at temperatures lower than $46^{\circ} \mathrm{C}$ or higher than $54{ }^{\circ} \mathrm{C}$, or to untreated controls.

In the second set of experiments, samples of the recipient cultures were exposed to the optimal temperature $\left(5 \mathrm{I}^{\circ} \mathrm{C}\right)$ for various periods. The results of six independent experiments are summarized in Fig. 2. Again the absolute value of the optimum frequency varied between experiments (from $\mathrm{I} \times \mathrm{IO}^{-6}$ to $5 \times \mathrm{IO}^{-5}$ ) but an optimum time of exposure was found within the range 2 to $3 \mathrm{~min}$.

This heat effect on fertility was not confined to the transfer of RY2drd2 to strain w227 only. Table 2 shows that three other $Y$. enterocolitica strains exhibited increased recipient ability for RY2drd2 after exposure to $5 \mathrm{I}{ }^{\circ} \mathrm{C}$ for $3 \mathrm{~min}$, and that heat-treatment of W227 increased its recipient ability for an Flac ${ }^{+}$factor.

\section{Isolation and properties of $Y$. enterocolitica mutants with an increased recipient ability}

The experiments in the previous section showed that the low recipient ability of $Y$. enterocolitica is determined in a positive way by a cellular factor having the same thermolability 


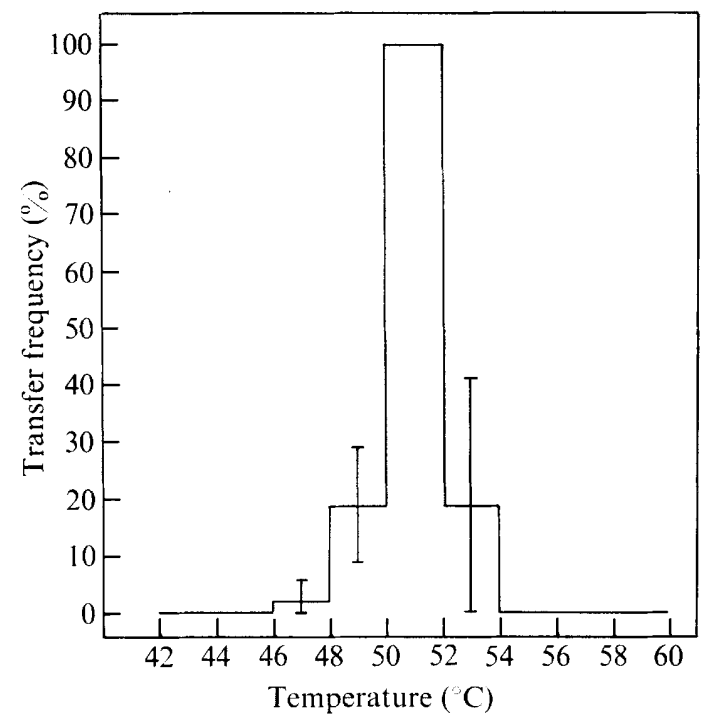

Fig. I

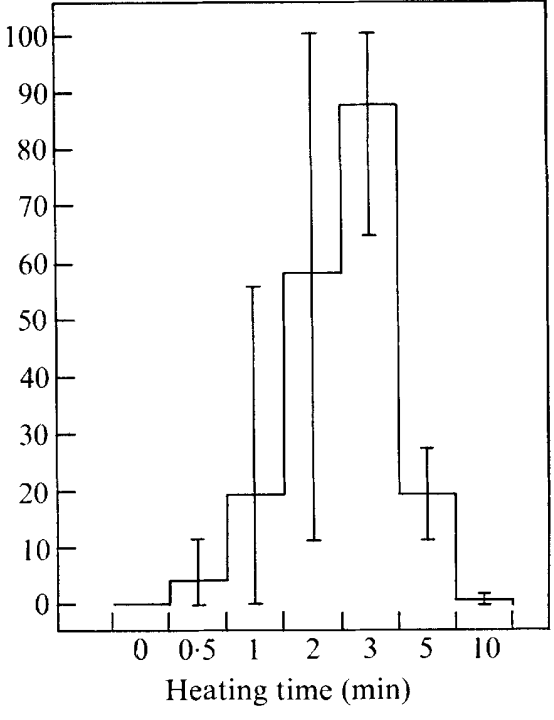

Fig. 2

Fig. 1. Optimum heating temperature for the transfer of RY2drd2 from E. coli $84 \mathrm{NX}$ to $Y$. enterocolitica w227. The heat treatments and matings were done as described in Methods. In each experiment, the highest frequency of transfer occurred in the 50 to $52{ }^{\circ} \mathrm{C}$ range and this frequency was taken as $100 \%$. Frequencies from the other temperature ranges were expressed as percentages of that at the optimum temperature. The results of five independent experiments were averaged. Bars represent the variation between experiments.

Fig. 2. Optimum time of heating at $5 \mathrm{I}^{\circ} \mathrm{C}$ for the transfer of $\mathrm{RY} 2 d r d 2$ from $E$. coli $84 \mathrm{Nx}$ to $Y$. enterocolitica W227. The heat treatments and matings were performed as described in Methods. The highest number of transfers was observed at $3 \mathrm{~min}$ in four experiments and at $\mathrm{I}$ and $2 \mathrm{~min}$ in two other experiments. For each experiment, the frequency of transfer at the optimum heating time was taken as $100 \%$. Frequencies from other heating times were expressed as percentages of that at the optimum time. The results of six independent experiments were averaged. Bars represent the variation between experiments.

as that which is characteristic of the restriction enzyme in several R-M systems (Arber \& Linn, I969). This suggested that restriction-deficient mutants of $Y$. enterocolitica with increased recipient ability could be isolated.

NTG mutagenized cultures of w227 were mated for $\mathrm{I} h$ in broth with strain $84 \mathrm{NX}$ and the transfer of RY2drd2 was selected. Under these conditions of mating, transfer of the $\mathrm{R}$ factor to wild-type W227 was not observed (see Table 2). Among five crosses with mutagenized cultures, two yielded respectively I and 3 I RY2drd2-infected clones. Six of these clones were subsequently cured of the R factor and their recipient ability for RY2drd 2 from $E$. coli was then compared with that of W227; this was done in membrane mating experiments rather than broth mating, to improve the overall frequency of transfer (McMahon, 197I). It was found that five of these six clones showed a more than Ioo-fold greater recipient ability than w227 (Table 3).

For most R-M systems in which restriction-deficient mutants were isolated, roughly half such mutants were found to be simultaneously deficient in the restriction and the modification functions. Therefore a series of crosses was performed, using each of these mutants as donor and a pair of streptomycin-resistant recipient strains. One derived from w227 (presumed restriction proficient, $\mathrm{r}^{+}$) and the other from the mutant w22703 (presumed restriction deficient, $\mathrm{r}^{-}$) (Table 4). Control crosses between wild-type strains showed that, once 
Table 2. Effect of heating on the transfer of $R Y_{2} d r d 2$ and Flac $^{+}$from $E$. coli to $Y$. enterocolitica

Cultures of the recipient strains were heat-treated at $5 \mathrm{I}{ }^{\circ} \mathrm{C}$ for 3 to $5 \mathrm{~min}$, then mated for $\mathrm{I} h$ in liquid.

\begin{tabular}{|c|c|c|c|}
\hline \multirow[b]{2}{*}{ Plasmid } & \multirow[b]{2}{*}{$\begin{array}{l}\text { Recipient } \\
\text { strain }\end{array}$} & \multicolumn{2}{|c|}{$\begin{array}{c}\text { Number of transfers per } 5 \times 10^{6} \\
\text { donors }\end{array}$} \\
\hline & & $\begin{array}{l}\text { Unheated re- } \\
\text { cipient strain }\end{array}$ & $\begin{array}{l}\text { Heated re- } \\
\text { cipient strain }\end{array}$ \\
\hline \multirow[t]{9}{*}{$\mathrm{RY} 2 d r d 2$} & w222 & $I \cdot 3$ & 18 \\
\hline & W222 & 0.3 & $\mathrm{I} \cdot 5$ \\
\hline & W230 & 48 & 439 \\
\hline & w227 & 0 & 24 \\
\hline & W227 & 0 & 380 \\
\hline & w227 & 0 & 500 \\
\hline & W277 & 0 & 2000 \\
\hline & w277 & 0 & 80 \\
\hline & w277 & 0 & 3 \\
\hline \multirow[t]{3}{*}{ Flac ${ }^{+}$} & w277 & $6 \cdot 3$ & 37 \\
\hline & w277 & $\mathrm{I} \cdot 5$ & 500 \\
\hline & W277 & $2 \cdot 7$ & II 7 \\
\hline
\end{tabular}

Table 3. Frequencies of transfer of $R Y 2 d r d 2$ from E. coli $84 \mathrm{~N} x$ to wild type and mutants of $Y$. enterocolitica with increased recipient ability

$\begin{array}{cccc}\begin{array}{c}\text { Recipient } \\ \text { strains }\end{array} & \begin{array}{c}\text { Frequencies of } \\ \text { transfer }\end{array} & \begin{array}{c}\text { Recipient } \\ \text { strains }\end{array} & \begin{array}{c}\text { Frequencies of } \\ \text { transfer }\end{array} \\ \text { W227 } & 7 \cdot 7 \times 10^{-6} & \text { W22707 } & 8 \cdot 1 \times 10^{-6} \\ \text { W22702 } & 1 \cdot 4 \times 10^{-2} & \text { W22709 } & 1 \cdot 3 \times 10^{-3} \\ \text { W22703 } & 5 \cdot 6 \times 10^{-3} & \text { W22701 } & 2 \cdot 7 \times 10^{-5} \\ \text { W22704 } & 9 \cdot 3 \times 10^{-3} & \text { W22708 } & 6 \cdot 3 \times 10^{-3} \\ \text { W22705 } & 1 \cdot 5 \times 10^{-2} & & \end{array}$

Table 4. Frequencies of transfer of $R Y 2 d r d 2$ between wild type and mutants of $Y$. enterocolitica with increased recipient ability

\begin{tabular}{llr} 
& \multicolumn{2}{c}{$\begin{array}{c}\text { Frequency of transfer to } \\
\text { recipient strain: }\end{array}$} \\
Donor strain & W2270I & W22708 \\
W227 & $5.0 \times 10^{-3}$ & $1.0 \times 10^{-2}$ \\
W22702 & $1.3 \times 10^{-2}$ & $5.0 \times 10^{-2}$ \\
W22703 & $1.2 \times 10^{-2}$ & $2.8 \times 10^{-2}$ \\
W22704 & $4.8 \times 10^{-3}$ & $6.1 \times 10^{-3}$ \\
W22705 & $5.8 \times 10^{-3}$ & $1 \cdot 2 \times 10^{-2}$ \\
W22707 & $2.4 \times 10^{-2}$ & $5.4 \times 10^{-2}$ \\
W22709 & $2.5 \times 10^{-3}$ & $4.0 \times 10^{-3}$
\end{tabular}

established in $Y$. enterocolitica, RY2drd2 is transferred at the higher frequency, comparable to that observed when it is transferred from $E$. coli to the presumed $\mathrm{r}^{-}$mutants. In the crosses with the mutant donors, the transfer of the $\mathrm{R}$ factor was observed at the high frequency to both the presumed $\mathrm{r}^{+}$and $\mathrm{r}^{-}$recipient strains. Thus all five mutants, representing at least two independent mutations, have the $\mathrm{r}^{-} \mathrm{m}^{+}$phenotype. 


\section{DISCUSSION}

Most R-M systems in bacteria have been first detected by their effect on the efficiency of plating of bacteriophages. However, it is well known that bacterial and plasmid DNA can also be affected by R-M systems. A lowered apparent frequency of transfer and of recombination is observed when recipient cells exercise a restriction against the donor-type DNA (Arber \& Morse, 1965).

Some R-M systems have been detected first from their effect on the recipient ability for plasmids and bacterial chromosome. Mutants with increased recipient ability were isolated and, in most cases, proven to be restriction-deficient, by measuring the efficiencies of plating of suitable bacteriophages (Colson \& Colson, I967; Okada, Watanabe \& Miyake, I968; de Graaf \& Stouthamer, 1971).

The mutants isolated in this study have not yet been characterized further with bacteriophages. All of them had the $\mathrm{r}^{-} \mathrm{m}^{+}$phenotype, in respect of their recipient and donor ability for RY2drd2. Thus these strains could not be used to produce phage lysates lacking the $Y$. enterocolitica modification in strains virtually isogenic to that with the wild-type $\left(\mathrm{r}^{+} \mathrm{m}^{+}\right)$ phenotype.

Further characterization of the R-M system(s) in our strains of $Y$. enterocolitica can be done in two ways. One is to isolate a phage with a broad host range, so that a 'natural host' lacking the modification would be available. The other is to isolate more fertile mutants, assuming that the absence of $\mathrm{r}^{-} \mathrm{m}^{-}$mutants in this study results from the small number of mutants obtained. However, some R-M systems are known in which all the mutations obtained had the $\mathrm{r}^{-} \mathrm{m}^{+}$phenotype (Yoshimori, Roulland-Dussoix \& Boyer, 1972).

In addition to the isolation of fertile mutants, the results of this work suggest the existence of an R-M system in $Y$. enterocolitica in two ways. First, the frequency of transfer of $\mathrm{RY} 2 d r d 2$ between strains of $Y$. enterocolitica is the same as that from $E$. coli to the $\mathrm{r}^{-}$ mutants, and $10^{3}$ times higher than from E. coli to $Y$. enterocolitica. Second, the conditions of heat-treatment for optimal transfer of plasmids from $E$. coli to $Y$. enterocolitica have been found to be closely similar to those which have been used to overcome phage restriction in Salmonella (Uetake, Toyama \& Hagiwara, I964; Mojica-a \& Middleton, 197I), in E. coli (Lederberg, 1965; Schell \& Glover, 1966) and Citrobacter freundii (de Graaf, Kreuning \& van de Putte, 1973).

G.C. is Aspirant du Fonds national de la Recherche Scientifique, Brussels, Belgium.

\section{REFERENCES}

Arber, W. \& Linn, S. (1969). DNA modification and restriction. Annual Review of Biochemistry $3^{8}$, $467-500$.

Arber, W. \& Morse, M. L. (I965). Host specificity of DNA produced by Escherichia coli. VI. Effects on bacterial conjugation. Genetics 51, 137-148.

Burrows, T. W. \& Gillett, W. A. (I966). The nutritional requirements of some Pasteurella species. Journal of General Microbiology 45, 333-345.

Colson, C. \& Colson, A. M. (1967). Host specificity and fertility in Salmonella typhimurium LT7. Biochemical and Biophysical Research Communications 29, 692-695.

Cornelis, G., Wauters, G. \& Bruynoghe, G. (I973a). Résistances transférables chez des souches sauvages de Yersinia enterocolitica. Annales de Microbiologie (Institut Pasteur) 124A, 299-309.

Cornelis, G., Wauters, G. \& Vanderhaeghe, H. (1973 $b$ ). Présence de béta-lactamase chez Yersinia enterocolitica. Annales de Microbiologie (Institut Pasteur) 124B, I39-152.

Falkow, S. \& Formal, S. B. (1969). Restriction in genetic crosses between Escherichia coli and Shigella flexneri. Journal of Bacteriology roo, 540-541. 
FrÉDÉRICQ, P. \& DelHALle, E. (1972). Recombinaisons entre facteurs R et facteurs colicinogènes chez Escherichia coli KI2. I. Production des recombinants. Annales de l'Institut Pasteur 122, 909-921.

GinozA, H. S. \& MATNEY, T. S. (I963). Transmission of a resistance transfer factor from Escherichia coli to two species of Pasteurella. Journal of Bacteriology 85, I177-1 178.

de Graaf, J., Kreuning, P. C. \& Van de Putte, P. (1973). Host controlled restriction and modification of bacteriophage $\mathrm{Mu}$ and $\mathrm{Mu}$-promoted chromosome mobilization in Citrobacter freundii. Molecular and General Genetics I23, 283-288.

De GraAf, J. \& Stouthamer, A. H. (1971). Citrobacter freundii mutants deficient in host specificity functions and their recipient ability for foreign deoxyribonucleic acid. Journal of General Microbiology 67, 9I-97.

KNAPP, W. \& Lebek, G. (1967). Übertragung der infektiösen Resistenz auf Pasteurellen. Pathologie und Microbiologie 30, 103-I $2 \mathrm{I}$.

LAWTON, W. D., Morris, B. C. \& Burrows, T. W. (I968). Gene transfer in strains of Pasteurella pseudotuberculosis. Journal of General Microbiology 52, 25-34.

Lawton, W. D. \& Stull, H. B. (197I). Chromosome mapping of Pasteurella pseudotuberculosis by interrupted mating. Journal of Bacteriology 105, 855-863.

Lawton, W. D. \& Stull, H. B. (1972). Gene transfer in Pasteurella pestis harboring the F'CM plasmid of Escherichia coli. Journal of Bacteriology I10, 926-929.

LEDERBERG, S. (1965). Host-controlled restriction and modification of deoxyribonucleic acid in Escherichia coli. Virology 27, 378-387.

McMahon, P. C. (197I). High frequency gene transfer in Pasteurella pseudotuberculosis. Journal of General Microbiology 69, 405-415.

MCMahon, P. C. (1973). Mapping the chromosome of Yersinia pseudotuberculosis by interrupted mating. Journal of General Microbiology 77, 6I-69.

MARTIN, G. \& JACOB, F. (1962). Transfert de l'épisome sexuel d' Escherichia coli à Pasteurella pestis. Comptes rendus hebdomadaire des séances de l'Académie des sciences 254, 3589-3590.

Meselson, M., Yuan, R. \& Heywocd, J. (1972). Restriction and modification of DNA. Annual Review of Biochemistry 4r, 447-466.

Meynell, E. \& Datta, N. (1967). Mutant drug resistant factors of high transmissibility. Nature, London 214, 885-887.

MojicA-A, T. \& Middleton, R. B. (197I). Fertility of Salmonella typhimurium crosses with Escherichia coli. Journal of Bacteriology 108, I16I-I 167.

Morris, B. C. \& BURrows, T. W. (I968). Gene transfer studies with 'Pasteurella pseudotuberculosis'. International Symposium on Pseudotuberculosis, Paris 1967; Symposia Series in Immunobiological Standardisation, vol. 9, pp. 275-284. Basel: Karger.

NilheN, B. (1969). Studies on Yersinia enterocolitica. Acta pathologica et microbiologica scandinavica 206, $\mathrm{SI}_{-} \mathrm{S}_{4} 8$.

OKada, M., Watanabe, T. \& MiYake, T. (1968). On the nature of the recipient ability of Salmonella typhimurium for foreign deoxyribonucleic acids. Journal of General Microbiology 50, $24 \mathrm{I}-252$.

Rolfe, B. \& HollowAy, B. W. (1969). Host specificity of DNA and conjugation in Pseudomonas aeruginosa. Genetics 6r, 34I-349.

Rusu, V., Baron, O. \& LAZAROAe, D. (1970). Transfert du facteur de résistance (R) des Enterobacteriaceae à Yersinia enterocolitica. Archives roumaines de pathologie experimentale et de microbiologie 29, 57 I-58r.

SCHELl, J. \& GLOVER, S. W. (1966). The effect of heat on host-controlled restriction of phage $\lambda$ in Escherichia coli. Journal of General Microbiology 45, 6I-72.

Uetake, H., Toyama, S. \& Hagiwara, S. (1964). On the mechanism of host-induced modification. Multiplicity activation and thermolabile factor responsible for phage growth restriction. Virology 22, 202-21 3.

Wauters, G. (1970). Contribution à l'étude de Yersinia enterocolitica. Thesis, University of Louvain. Edited by Vander.

Wauters, G., Le Minor, L. \& Chalon, A. M. (I971). Antigènes somatiques et flagellaires des Yersinia enterocolitica. Annales de l'Institut Pasteur I20, 63I-642.

WINBLAD, S. (1967). Studies on serological typing of Yersinia enterocolitica. Acta pathologica et microbiologica scandinavica 187 , SI 15.

Yoshimori, R., Roulland-Dussoix, D. \& BoyeR, H. W. (1972). R factor-controlled restriction and modification of deoxyribonucleic acid: restriction mutants. Journal of Bacteriology II2, I275-1 279. 